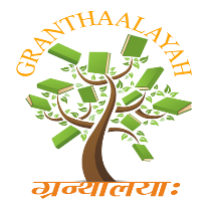

\author{
INTERNATIONAL JOURNAL OF RESEARCH - \\ GRANTHAALAYAH \\ A knowledge Repository
}

Social

\title{
USEFULNESS OF EDUBLOGS AS A TOOL TO ENHANCE TEACHING LEARNING PROCESS AMONG STUDENT TEACHERS
}

\author{
Monika Singh ${ }^{1}$, Prof. Purnima Gupta ${ }^{2}$, Prof. Vandana Goswami ${ }^{3}$ \\ ${ }^{1}$ Research Scholar, Faculty of Education, Banasthali Vidyapith, Rajasthan, INDIA \\ ${ }^{2}$ Principal, DDR College of Education, Gurgoan, INDIA \\ ${ }^{3}$ Dean, Faculty of Education, Banasthali Vidyapith, Rajasthan, INDIA
}

DOI: https://doi.org/10.29121/granthaalayah.v4.i11.2016.2419

\section{ABSTRACT}

The present paper explores one of the most important aspects related to every sector today, including education - the integration of information and communication technology in day to day working. Along with the pedagogical content knowledge, teachers also need to be well versed with the ICT skills and also in the various tools that can be effectively be used to enhance their teaching. Weblog or Edublog of web 2.0 technology is one such tool that has the potential to augment and encourage student engagement and inspiration outside the classroom. The 21st century technology is needed in teaching and learning and applying these skills in a contemporary environment is becoming most essential. Edublogs as a tool and their uses in education have been discussed here. Edublogs are helpful in concerted learning, new knowledge construction and skill expansion that can help the student teachers in their professional development.

Keywords:

Teaching, Learning, Student, Teacher.

Cite This Article: Monika Singh, Prof. Purnima Gupta, and Prof. Vandana Goswami, "USEFULNESS OF EDUBLOGS AS A TOOL TO ENHANCE TEACHING LEARNING PROCESS AMONG STUDENT TEACHERS" International Journal of Research Granthaalayah, Vol. 4, No. 11 (2016): 44-51.

\section{INTRODUCTION}

India's education system has seen many a new modifications or transitions but the desire of having a high tech education which is as per today's need and requirement accessible to all seems far to be achieved. With the recent launch of Digital India Campaign by our Prime Minister, Mr. Narendra Modi, it is expected that many areas chiefly commerce, banking, health, governance and education will be impacted. Education, as mentioned, is supposed to be one of the important elements of this plan. Will this Digital India Campaign help education become modern and reachable to all and if yes then, how would this new initiative be fruitful? 
Modern technologies are day by day being increasingly used by everyone in our everyday lives so that we can easily connect with each other and also share information on many day-to-day issues, including education. Inventive technologies today are creating new forms of adaptive and peer learning, increasing access to trainers and mentors and providing useful data in real time. 'Digital India' is expected to be a promising panorama to use technology to give a new lease of life to our education system to deal with the huge learning crisis that our country faces. 'Digital India', implemented with vision and assurance, can catalyze pioneering initiatives by creating an enabling environment across the country. Plan to connect the rural areas with high speed internet networks is also a part of this initiative. The three important components of Digital India in the field of education are:-

1) Formation of digital infrastructure in terms of computing resources in educational organizations.

2) Providing services digitally in terms of e-resources.

3) Develop proficiency in using ICT enabled services.

We, in the $21^{\text {st }}$ century, are living in a knowledge based society where knowledge is power, economy and strength of an individual and an asset to a developing nation. ICT can definitely play a very important role in this, since we need new technologies to have access and make proper use of this fast growing knowledge. This can happen not just by mere acquisition of knowledge but with its manipulation to our advantage with the support and assistance of science and technology in the form of ICT. ICT can be utilized in shape of various tools, equipments, application and support that can help in the collection, storage, retrieval, use, transmission, manipulation of information accurately and efficiently for the purpose of enriching the knowledge, enabling decision making, developing communication and increasing the problemsolving ability of the user. The term ICT refers to the technologies which are being used for collecting, storing, editing and passing on information in various forms. (SER, 1997) Many of the modern ICT tools are easily available in profusion today. These tools are a combination of hardware and software, media and delivery systems. In addition, they have gone digital, like laptops, LAN, PC, digital libraries, world wide web, virtual classrooms, internet etc.. Digital Literacy, which means the basic knowledge of ICT tools for educational purposes, in the present scenario, is considered the most fundamental and basic skill by the education systems. ICT increases the flexibility so that students can access educational resources regardless of time constraints and geographical barriers. Collaborative and cooperative development of skills and abilities to create knowledge are also enhanced. It can improve the overall learning excellence. It is predicted nowadays that ICT proves to be beneficial for both the teacher as well as the learner. It basically includes:-

1) Shared learning resources

2) Promotion of collaborative learning

3) Shared learning spaces

4) Independent learning

Globally, various researches have also shown that ICT can lead to enhanced student learning and better teaching strategies and techniques. A report made by Japan proved that the more the students are exposed to educational ICT through curriculum integration, the more noteworthy and positive is the impact on student achievement, especially in terms of knowledge, comprehension, practical skills and presentation skills in various pedagogy subjects like 
mathematics, science and social studies. A study conducted by Xavier Institute of Management in Bhubaneswar in 2007 revealed that computer aided education, in which children are taught through computers using multimedia based educational content, improved the performance of children in Mathematics, Science and English.

Generally the following levels of the use of ICT in education are described in literature (SER, 1998, Moonen and Kommers, 1995, Pilot 1998) -

1) ICT as an object: - This means learning about ICT. This is mostly organized in a specific course and what is being learned depends on the kind of education and the level of students. This would in turn prepare the students for the use of ICT in education, future occupations and social life.

2) ICT as an assisting tool: - By this is meant that ICT is not learnt as a subject but is used in other subjects for various purposes like making assignments, collecting data, communicating and conducting research etc.

3) ICT as a medium for teaching and learning: - Different mediums can be adopted by teachers to teach their students making direct use of ICT. It appears in many different forms, such as drill and practice exercise in simulations and educational networks. This also provides a means of self-learning by the students.

4) ICT as a tool for organization and management in schools: - Various ICT tools and software is used for educational management and organization.

\section{MAIN ADVANTAGES OF ICT TOOLS FOR EDUCATION}

1) ICT enables the use of multiple senses in teaching and learning and thus plays a part in improving the retentive memory of students.

2) Through ICT, teachers can easily make use of various tools and strategies to explain complicated topics in an interesting and easy way to ensure better students comprehension.

3) Teachers can easily create interactive classes and make the lessons more interesting and enjoyable for the students which could, in turn, improve students' attendance and concentration.

4) ICT helps in revolutionizing the system of education by providing both the resources and pedagogical framework for enabling pupils to become effective independent learners

5) It helps in individualized instruction.

6) It acts as a motivating strategy and tool with neat work with no red marks by the teacher all over it.

7) ICT can also help to satisfy the urges of curiosity, constructing knowledge and inventiveness.

8) It helps students to extract required information and use methods of information processing.

Technology also helps in connecting with each other. Schools are making beneficial use of various digital devices like laptops and tablets to swiftly, easily and inexpensively connect students with enormous and ever-growing number of instructive tools and assets and subject matter experts in their fields over the internet. Teachers are using online networks and social 
media to connect with other schools and peer who can help them acclimatize with their teaching practices to make the most out of these digital tools. Students are using digital technologies to unite with other students across the country and across the world, and to engage in self-directed learning in areas of personal interest and expertise. Many of us use technology to connect to information and learning whenever and wherever we choose. The Indian Government announced 2010-20 as the decade of transformation. New ways of thinking and ICT skills are necessary for advancement in all the fields in India. The foundation of these skills is laid at the base level i.e, starting from the school education.

In their position paper for NCF 2005, the Focus Group also suggested the following uses of ICT:

\section{To refresh and update skills of in-service teachers:}

1) Create a mechanism for the consistent development of teaching and administrative skills, especially for educational leaders and managers such as headmasters and principals.

2) Promote ICT awareness to carry on the educational work creatively and efficiently.

3) Help in developing and fostering teachers' self-help groups/professional development groups.

\section{For pre-service teacher education:}

1) Making future teachers aware about the varied flexible models that can be used for reaching curriculum goals.

2) Familiarizing them with media and ICT-aided methods of learning, making them an integral part of the teaching-learning process of teachers.

3) Imparting training in evaluating available ICT materials and integrating them into the learning process.

4) Enabling teacher trainees to access the varied sources of knowledge and to construct new sources of knowledge.

\section{For school education:}

1) Shifting the focus from pre-determined outcomes and skill sets to one that enables students to develop innovative reasoning and other higher-order skills.

2) Enabling the students to use sources of knowledge and interpret them, and to construct knowledge rather than be passive users of knowledge.

3) Promoting flexible models of transacting the curriculum.

4) Encourage individual learning styles.

5) Promoting use of flexible curriculum content, especially at the elementary level, and using flexible models of evaluation.

In the National Curriculum Framework for Teacher Education by NCTE (2009-10) a growing concern about the actual use of ICT tools has been expressed. The document points out that there is an increasing demand that ICT tools be used to impart school education. To have computers or multimedia has become more of a fashion statement in schools, and in spite of its potential to make learning energizing; its implementation is generally very superficial. ICT is seen as a 
measure to overcome the shortage of teachers. These practices are detrimental to the learning of the child. Teacher education should strengthen itself so as to sensitize the teacher to distinguish between critically useful, developmentally appropriate use and the detrimental use of ICT. ICT should be inventively used for professional development and academic support of the pre-service and in-service teachers.

ICT tools and techniques which are affordable can be integrated into classroom instructions right from the primary stage so as to facilitate students in developing of their required skills.

1) At the primary and upper primary level, the objective may be to enable students to simply access the available information.

2) At the secondary level, students should be trained to collect and arrange data and to compute to reach at conclusions in any subject, not only in Mathematics and Science.

3) At the senior secondary level, students should use ICT tools in discussing and sharing different approaches in solving complex multidisciplinary problems relating to areas like environmental science, nanotechnology, business intelligence, biochemistry and bioinformatics etc. In today's scenario, the students and the teachers together should be able to work collaboratively in a global competitive environment.

For Digital India to make an impact on education, it needs a synchronized and besieged approach to integrate technology to our vast and complex education system. Technology can help to generate individual learning paths for children, making teaching learning process interactive, interesting and fun and can provide them abundant practice opportunities. To encourage the use of technology in classroom teaching, it is important to build advance learning tools to deal with the multiplicity of languages and state curricula. To meet these educational needs, the content could either be developed in the vicinity or else, high quality worldwide content could be limited to a small area. Many such tools, techniques and tutorials today are accessible in the open domain and on the web. The Government of India has, for this purpose, launched the National Repository of Open Educational Resource in 2013 to build a repository of high quality content in local languages.

ICT provides an array of tools like computer conferencing, audio-video conferencing, teleconferencing and also computer enabled learning, also called as web-based learning, which provides incorporated environments of various technologies to support miscellaneous needs of the learner via the internet. This helps in changing the educator centered approach like textbook bound class rooms into student centered, interactive knowledge environments.

\section{WEB 2.0 TECHNOLOGIES}

ICT tools, in varied forms, have been an integral part of teaching, learning process. It is among the resources that teachers use to help facilitate students' learning. Technologies have changed significantly over recent decades. There are many technologies used for various purposes. Among these technologies, Web 2.0 technology is a new concept that has revolutionized the way in which users interact with the World Wide Web.

There are a large number of web-based services and applications that exhibit the foundations of the web 2.0 concept. These web- based services can prove to be reforming tools for rapid 
transformation in the higher education. Some of these are - wikis, face book, blogs and youtube etc. Web 2.0 services and technologies can offer wider learning options easily available to educators as well as the learners. These services and technologies facilitate a more open approach to learning and to the ability to access and share educational material, create derivative works, republish and redistribute these works. They provide access to a variety of learning materials, meet teachers' needs and focus on specific outcomes. Web 2.0 is a term used to describe a change to a more vivacious participatory and social web. Education is also a beneficiary of such change. Teachers can shift their attention away from the technology itself to the pedagogy to find the best value and most correct uses of web 2.0 technology in enhancing teaching and learning as these web 2.0 technologies are easier to use and have become more widespread place in education. Among the various tools that can be used for the educational purposes 'Edublogs' is one of them.

\section{BLOG (WEBLOG) TECHNOLOGY IN ENHANCING TEACHING AND LEARNING}

Blog (weblog) technology enables active and insightful learning as users regularly publish personal content on the web. The weblogs have a number of applications in education also for professional development of the teachers. There are schools where teachers and the students are regularly creating and maintaining weblogs as learning projects along with the other processes and activities in the classroom. It is said that blogs are online diaries which has user generated content uploaded regularly. The content uploaded is in the reverse sequential order therefore making it a completely available application for all. There is also an option in these to invite comments, to expand on and share experiences. It does not require any programming language or server knowledge from the bloggers. It can be used for news, reviews, personal thoughts, web links, and photographs and so on. These also include text, images, links as well as multimedia files. Among the different blogs, many blog tools are available for free, like Edublogs (www. Edublogs.org). These Blogs can encourage open dialogue and collaborative learning in which both the teachers and learners can exchange ideas, attitudes and opinions outside the conventional classroom. Teachers can also let students to set up their own blog. Richardson (2004) points to the fact that blogging is a new sort of writing which has "great significance in terms of developing all sorts of critical thinking skills, writing skills and information literacy". Blogs have the potential to alter the way teaching and learning activities are carried out by providing self-sufficiency and interactivity with the peers. Among other things, blogging provides individuals a chance to-

1) Disapprove of what they are writing and thinking as they write and think it.

2) Write about a topic over a persistent period of time - may be a life- time.

3) Keep the readers and audience engaged in continuous conception and thinking, that leads to further writing and thinking.

The most effective learning is achieved through a structured combination of different approaches like online learning through such tools as Edublogs, face to face instruction self-study material and so on. These things are somewhere deficient in our conventional education. By giving students access to the technology tools like weblog (Edublogs) teachers can give students the opportunity to share what they learn collaboratively with their teachers and also with their peers. Blog technology enables students to actively collaborate in the formation of new content rather 
than consume the existing content. This technology promotes a flexible approach to learning. Blogs become a forum for public expression and this is required for the educators who are engrossed in enlightening and revising their thinking about teaching and learning.

\section{USES OF EDUBLOGS IN EDUCATION}

- A good communication tool for the teachers and the students from any location.

- Provides detailed information to the students at a time.

- Allows students to post the assignments and homework.

- Engages students in active learning.

- Allows students and the parents to comment on the post.

- Develops high order thinking.

- Improves flexibility in teaching and learning.

- Provides a supportive environment for reading and writing.

- Edublogs become forum for public expression.

- Promotes participation, increases students curiosity in the discipline.

- Provides opportunities for the varied perspectives both within and outside the classroom.

- Engages students in knowledge sharing and manifestation.

- These allow users to act in response, to generate and to bond.

\section{CONCLUDING REMARKS}

Thus, Edublogs have many uses in education that can be incorporated by the student teachers in their teaching and in the overall educational system effectively to get updated with the technological developments and can also be beneficial for their own professional development as a teacher. Most of the blog services are user friendly and functioning on a blog is more or less comparable to the word processing application in windows. These skills are required by today's generation to succeed in the most progressive workplaces. So, if one has the confidence about his/her thinking and writing ability, he/she should consider starting his/her own Blog.

\section{REFERENCES}

[1] Alison Hraniak, Helen Boulton and Brian Irwin (2009) .Teacher trainees "Use of Blogs as private reflections for professional development Journal learning media and technology" vol 34 issue 3,(259-269)

[2] Anderson, P. (2007). web 2.0 ideas, technologies, implications for education, JISC technology and standards watch retrieved April 28, 2008.

[3] Blood, R. (2004a). How blogging software reshapes the online community Communications of the ACM, 47(12), 53-55.

[4] Blood, R. (2002b). The Weblog Handbook: Practical Advice on Creating and maintaining Your Blog. Cambridge, MA: Perseus Publishing.

[5] Blood.R. (2000a). Weblogs: a history and perspective, Rebecca's Pocket, 7 September.

[6] Brooks. K, Nichols. C and Priebe. S (2004). Remediation, genre, and motivation: Key concepts for teaching and Weblogs. Retrieved March 28, 2007, from http://blog.lib.umn.edu/blogosphere/remediation genre pf.html 
[7] Dash, Manoj Kumar. (2010). ICT in teacher education, New Delhi Neelkamal publications Pvt limited, 1-16.

[8] Dearstyne, B. W. (2005) .Blogs: The new information revolution Information Management Journal, 39(5), 38-44

[9] Mangal, S.K and Uma Mangal (2013). Essentials of Educational Technology, New Delhi PHI Learning Pvt limited, 697-704.

[10] National curriculum Framework (2005). New Delhi: NCERT.

[11] National curriculum framework for teacher education (2009/10), NCTE, New Delhi.

[12] O'Reilly, T. (2005). what is web 2.0, Design patterns and business models for the next generation software. O'reilly Media Inc. retrieved April 28, 2008.

[13] www.scholargoogle.com

[14] http://edublogs.org

[15] www.journalselsevier.com 